\title{
Book Review on Social Entrepreneurship and Tourism: Philosophy and Practice (Tourism on the Verge) Edited by Pauline J. Sheldon \& Roberto Daniele
}

\author{
Sayuni B. Mariki, Robert B. Modest \\ College of Forestry, Wildlife, and Tourism, Sokoine University of Agriculture, Morogoro, Tanzania \\ Email: zion2000tz@gmail.com
}

How to cite this paper: Mariki, S.B. and Modest, R.B. (2017) Book Review on Social Entrepreneurship and Tourism: Philosophy and Practice (Tourism on the Verge) Edited by Pauline J. Sheldon \& Roberto Daniele. Open Journal of Business and Management, 5, 470-475.

https://doi.org/10.4236/ojbm.2017.53040

Received: May 18, 2017

Accepted: July 7, 2017

Published: July 10, 2017

Copyright $\odot 2017$ by authors and Scientific Research Publishing Inc. This work is licensed under the Creative Commons Attribution International License (CC BY 4.0).

http://creativecommons.org/licenses/by/4.0/

\begin{abstract}
This book "Social Entrepreneurship and Tourism: Philosophy and Practice" edited by Pauline J. Sheldon and Roberto Daniele is a recent addition to Springer's "Business and management" series. The book aims at advancing knowledge of tourism and social entrepreneurship. It explores the tourism social entrepreneurship both in theory and practice (by using case studies from several countries), and sets forth a ground for future research and education. The book is divided into three main sections. As expected, this book would contribute to studies of tourism, entrepreneurship and/or development. Specifically, the book will be eminently suitable as a text for courses to students, and of interest to academics, researchers, and those involved in tourism social entrepreneurship as it presents a wealth of information combined with a diverse range of views on the subject.
\end{abstract}

\section{Keywords}

Enterprise, Entrepreneurs, Innovation, Social Entrepreneurship, Tourism

With a focus of advancing knowledge of tourism and social entrepreneurship, the authors explore the tourism social entrepreneurship both in theory and practice by using case studies from different countries. The book ends by setting forth a ground for future research and education.

In the introductory chapter, the authors state that "tourism exists within the turbulent world [which the author highlight as shocks and disturbing problems-such as climate change, environmental degradation, economic imbalances and inequalities, social justice, and human rights], and the call for more sustainable, resilient and responsible tourism development is getting louder" p. 2. 
They continue to highlight that "if tourism is to thrive in the future, a more agile, responsive and forward looking industry is necessary to help society move through these profound changes" p. 2. The authors further stress that, these environmental issues "cannot be addressed without making progress on pressing social issues such as poverty, gender equity, empowerment and inclusion" p. v. The authors go on by stating that the tourism model (production-consumption model) is now exhibiting signs of stress evidenced by overuse of physical resources (land, landscapes, water, wild lands etc.), congestion, increasing costs for infrastructure and regulatory administration, diminishing return, and reduced yields.

The social entrepreneurs in this book are regarded as society change agents, who disrupt the status quo, transforming the world for the better-by changing the current situation. The authors have built on [1] definition of social entrepreneurship (process that creates innovative solutions to immediate social problems and mobilizes the ideas, capacities, resources, and social agreements required for this suitable transformation) to generate the definition of tourism social entrepreneurship (TSE) - "a process that uses tourism to create innovative solutions to immediate social, environmental and economic problems in destinations by mobilising the ideas, capacities, resources and social agreements, from within or outside the destination, required for its sustainable social transformation."

The book comprises three main sections. The first section has six chapters that focus on conceptual and theoretical framework. The chapters provide framework for building an understanding of the connection between social entrepreneurship and tourism, and suggest new models. The first chapter is titled "Theorising Social Entrepreneurship within Tourism Studies”. The chapter place social entrepreneurship and tourism within various theories of social value, entrepreneurship and innovation. The discussions mainly focus on types of institutional sectors encompassing social entrepreneurship (public, profit and non-profit). The chapter conclude by proposing two areas for investigation-the nature of social entrepreneurs as key actors involved in sustainable tourism development and the interactions between social entrepreneurs and resident/host communities they serve.

The second chapter "Institutional and Policy Support for Tourism Social Entrepreneurship in Tourism" addresses policy issues that can be taken into considerations by different actors in tourism sector (governments, planners and policy makers) to develop and promote TSE sector. The chapter suggest ways governments can create the conditions to enhance flourishing of tourism social entrepreneurship-1) developing policies that encourage and support development and operation of social enterprises; and 2) assisting in creation of institutional conditions, encourage, legitimize and synergize social entrepreneurship. The authors further stress that "social entrepreneurship does not exist in a vacuum, but is shaped by institutional rules, routines, structures and cultures which governments have some influence" p. 51. 
The third chapter "Social Entrepreneurship Typologies and Tourism: Conceptual Framework" focuses on ways social entrepreneurs (SE), and socially-entrepreneurial organizations have been categorised. For instance, SEs are categorised in terms of their personal traits and characters, organizational context, work/leadership style, activities they undertake etc. The chapter also explores how different forms of social entrepreneurs fit different hospitality environments and destinations.

Chapter four "Business Models for Social Entrepreneurship in Tourism" present and analyse different operational business models appropriate for tourism and hospitality. In the conclusion part, the authors argue for more extensive use of the business model construct by tourism social entrepreneurs to help them become more successful and sustainable. The fifth chapter-"Social Innovations in Tourism: Social Practises Contributing to Social Development" examine contribution of social entrepreneurship into social development in tourism. Using examples from tourism, the authors discuss new technologies and their effect on transforming social practises on social innovations.

The last chapter titled "Understanding how Social Entrepreneurs Fit into the Tourism Discourse", places the research of social entrepreneurship and tourism in the context of other research threads and themes in tourism. The authors further examine the four important terms-tourism entrepreneurs, sustainability, destination development, and social intrapreneurship. The authors encourage researchers to expand the current knowledge base and extend the scope of research on the topic.

The second section is called "Communities of Practise". The section consists of three chapters, and focuses on communities where social entrepreneurship in relation to tourism is practised. The first chapter "Exploring Social entrepreneurship in Food Tourism" examines social entrepreneurship in food tourism ventures, a sector which is critical to a healthy tourists and healthy tourism industry, and one which advances itself well to social enterprise development and networks. The chapter point out the importance of influencing the supply chains of tourism social entrepreneurs. The findings also reveal that food entrepreneurs are consciously focused on value creation beyond the revenue generated by their business.

The following chapter "Knowledge Dynamics in the Tourism-Social Entrepreneurship Nexus" focuses on knowledge dynamics and knowledge creation in the context of social entrepreneurship and tourism. The authors argue that by being enriched with an understanding of cross-sectoral knowledge dynamics, the overall praxis of tourism and social entrepreneurship can be strengthened, and in particular will assist policy makers in fostering conditions that generate increased innovation.

The last chapter-"Social Enterprise Evaluation: Implications for Tourism Development" focuses on measurement and evaluation of social enterprises and on how it contributes to tourism development. The authors argue that traditional approaches to evaluation may be limited in supporting social entrepre- 
neurship projects with development objects of empowerment and societal change. They propose social enterprise projects that enhance community participation. They emphasized that these projects may be better positioned to achieve their development objectives by incorporating more of the principles of Participatory Evaluation and Empowerment Evaluation.

The last section of the book explores different case studies from eight countries (Australia, India, Israel, Malaysia, Mexico, Mozambique, Nepal and Romania) where SE has an impact. Each chapter give details of the characteristics of the enterprises, the gaps and opportunities they came across, and the lesson learned. The authors have evaluated critical success factors and they have presented several questions at the end of each case for discussion. The first chapter "Social Entrepreneurship and Tourism Development in Mexico: A Case Study of North America Social Entrepreneurs in a Mexican Town" examines social enterprise development in Mexico which is largely driven by expatriates from USA. The chapter highlights the dynamics of various stakeholders in the area and importance of mobilising collective interaction, trust, and collaborative activities within them. The chapter stresses the necessity of seeing social entrepreneurship in the context of broader social-economic networks.

In the following chapter, "Heroic Messiahs or Everyday Businessmen? The Rhetoric and the Reality of Social Entrepreneurship in India", the authors use cases of two social entrepreneurs in responsible tourism in India to confirm, and challenge, the continued myth of regarding social entrepreneurs as an isolated "heroes". They deconstruct such perceived myth by suggesting a relevant conceptual framework. The chapters "Guludo Beach Lodge and Nema Foundation, Mozambique", and "Adventure Alternative and Moving Mountains Trust: A Hybrid Business Model for Social Entrepreneurship in Tourism" have similar theme. Both chapters examine a peculiar social enterprise business model. The model comprises of a dual-structured social enterprise-the tourism/hospitality business, and charity which delivers social impact by achieving community's needs and interests. The chapters also analyse the synergies, potentials, strengths and weaknesses.

The chapter "The BEST Society: From Charity to Social Entrepreneurship", the case from Malaysia focus on charities moving away from traditional models to a social entrepreneurship model. The situation of charities not relying on government support is expected to grow overtime due to government budget cuts funding. Thus, through a "diffusion of innovation", the social enterprise model becomes more effective in this case. To full implement social entrepreneurship model, the authors have proposed a four step community tourism development models.

The next chapter "Social Enterprise Ecosystems: A Case Study of the Danube Delta Region of Romania" address the optimal conditions that enable social enterprise activities to materialise, grow and blossom into sustainable organizations. It shows the importance of developing ecosystems for social enterprises.

The chapter titled "The Influence of Social Entrepreneurship in Tourism on 
an Arab Village in Israel" focuses on the development of a first commercial accommodation unit called Juha's Guesthouse in the Arabia village in Israel. The facility is established in the community characterised by deep and systematic cross-cultural conflict. The guesthouse is operated through special Arab-Jewish partnership. The authors demonstrate that social entrepreneurship approach to tourism development can bring new hopes for economic and development and social cohesion, as well as help stakeholders to overcome underlying negative experiences and attitudes.

The last chapter under this section is titled "Walking on Country with Bana Yarralji Bubu: A Model for Aboriginal Social Enterprise Tourism" focuses on a family run Aboriginal social enterprise in Australia. Authors expresses the challenges of setting up a social enterprise in a context of negative social capital existing in the local community, and the impact of external factors such as land use planning, land administration systems, the political environment, and the tourism market.

The concluding chapter considers the "role the research and education can play to move the TSE agenda forward. In addition to consolidating the chapters about the future of SE and tourism, it also lay out some directions for research tracts in the future. It considers the changes needed in research approaches, in universities, curricula, learners, and academics. These changes are expected to stimulate the dialog on how TSE can mobilize the energy, vision and social spirit of those who seek to change the word for better through tourism" P. 317. The authors acknowledge that social entrepreneurship is a quite a new area, and that further research would be beneficial. Thus, there is a need to "build bridges with practise, to engage in the field and to unlock the practical wisdom that resides in tourism social entrepreneurs themselves" p. 329.

Tourism social entrepreneurship - an umbrella term to capture a range of innovative approaches and models for tourism that deliver blended economic, social and environment value is explored in the book chapters. However, the authors have deconstructed the claims which (usually) "assign a positive value to tourism prior to the research actually taking place." These statements include "tourism results in social, economic and environmental value" or "tourism is inherently good". In the process, "any real understanding about the strength and weaknesses of tourism, and the value its produces in different settings and various stakeholders are obscured in the pursuit of making the point about tourism's importance" p. 307.

The authors' interest in this book was "to offer a more variegated and situated appraisal of TSE, and avoid polemic claims about its value before people can real understand its nature," Authors believe that "tourism industry must be substantially re-imagined and re-designed if it is to become a net positive contributor to society and planetary wellbeing" p. 318. They hope that the book will be "a catalyst for more radical social innovation in tourism and call for actions for future change-makers in this extraordinary field of human endeavour".

The book is interesting, stimulating and informative, and it inspires tourism 
social entrepreneurs to take action and researchers to continue searching and acquiring knowledge. Readers will enjoy reading this book as it draws together a range of thoughts from a number of disparate disciplines. The principal outcome is that TSE "pushes the opportunity for meaningful action."

The book is therefore a "very welcome contribution and, hopefully, the start of a journey that contributes to changing and refocusing tourism social entrepreneurship on its world-making potential" p. vi. The book is eminently suitable as a text for courses on tourism, entrepreneurship and/or development and each chapter includes abstract at the start, description and/or case studies, discussion questions, and references at the chapter close. These features enhance the book and make it extremely useful for students. In addition the book will be of interest to academics, researchers, and those involved in tourism social entrepreneurship as it presents a wealth of information combined with a diverse range of views on the subject.

We enjoyed reading this book and recommending it to others. It is an interesting, and at times provocative, account of the tourism social entrepreneurship. It is wide-ranging, thoughtful, and insightful, global in scope and comprehensive in coverage. The authors are to be commended for putting together this timely initiative which will surely be the benchmark text in this subject for many years to follow.

\section{References}

[1] Alvord, S.H., Brown, L.D. and Letts, C.W. (2004) Social Entrepreneurship and Societal Transformation: An Exploratory Study. Journal of Applied Behavioural Science, 40, 260-282. https://doi.org/10.1177/0021886304266847

Submit or recommend next manuscript to SCIRP and we will provide best service for you:

Accepting pre-submission inquiries through Email, Facebook, LinkedIn, Twitter, etc. A wide selection of journals (inclusive of 9 subjects, more than 200 journals)

Providing 24-hour high-quality service

User-friendly online submission system

Fair and swift peer-review system

Efficient typesetting and proofreading procedure

Display of the result of downloads and visits, as well as the number of cited articles

Maximum dissemination of your research work

Submit your manuscript at: http://papersubmission.scirp.org/

Or contact ojbm@scirp.org 